\title{
Range Rehabilitation Enhances Cotton Rats in South Texas
}

\author{
FRED S. GUTHERY, TERRY E. ANDERSON, AND VALGENE W. LEHMANN
}

\begin{abstract}
During August 1961 in Kleberg County, Texas, cotton rat density was four times greater on areas planted to exotic grasses than on native rangeland, and density was six times greater on rootplowed areas. A regression model using standing crop biomass of herbaceous vegetation and percentage composition of standing crop furnished by sida, bristlegrasses, and sumpweed plus ragweed explained $81.4 \%$ of the variation in cotton rat density.
\end{abstract}

Rodents play important roles in the ecology and management of rangelands (Gross 1969; Vallentine 1971). These animals may positively (Bond 1945) or negatively (Norris 1950) influence plant succession. Although small herbivores usually dissipate less than $5 \%$ of the energy stored in net primary production (Chew and Chew 1970; French et al. 1976), their activities can further curtail herbage production. Fitch and Bentley (1949) reported that rodent populations are potentially capable of removing $33 \%$ of the annual forage production on California rangelands. This results from trampling of vegetation and from close cropping during the growing season. Foster (1965) found that grazing by microtine rodents removed current-season stem primordia of perennial grasses in southeastern Idaho. A population of 160 voles (Microtus sp.)/acre in California removed $85 \%$ of the volume of vegetation and diminished seed fall from grasses in the vole diet by $70 \%$ (Batzli and Pitelka 1970). Clearly, knowledge of factors influencing rodent population dynamics is necessary for full understanding of plant community dynamics.

During 1958 through 1960, cotton rat (Sigmodon hispidus) irruptions (Haines 1963) occurred in Texas. Densities were still exceptionally high in portions of south Texas during the summer of 1961, where Anderson (unpublished report) removed 310 cotton rats from 2.07 acres during a 96-hr period. The apparent density, ignoring ingress and peripheral areas of influence, was 149/acre. On a second area of similar size, Anderson removed 75/acre during a 24-hr period. Davis (1974) reported that several hundred rats per acre are not uncommon during such irruptions.

The purpose of this paper is to compare cotton rat densities during the 1961 irruption between improved and unimproved rangeland, and to examine habitat features that aided in explaining differences in rodent density among range treatments.

Guthery is assistant professor, Department of Range and Wildlife Management. Texas Tech University, Lubbock. At the time of the research, Anderson was with the U.S. Fish and Wildlife Service, San Antonio. Texas, and Lehmann was wildlife hiologist for King Ranch, Inc., Kingsville, Texas. Anderson's current address is 2229-A South Holke Road Independence, Missouri, and Iehmann's is P.O. Box 185, Carrizo, Springs, Texas.

The authors thank V.W. Lehmann, Jr., and W. Turner for field assistance.

This paper is publication number T-9-194 of the College of Agricultural Sciences,

Texas Tech University.

\section{Study Area and Methods}

Data were collected on the Santa Gertrudis Division of the King Ranch, Kleberg County, Texas, during August 1 to August 24, 1961. Topography was flat to gently rolling and soils were sandy clay loams of the Czar-Delfina-Orelia Association.

Treatments consisted of improved grasslands, native range, and rootplowed areas. Improved (rootplowed and seeded) areas had an herbaceous stratum dominated either by King Range bluestem (Bothriochloa ischaemum) or buffelgrass (Cenchrus ciliaris), which are introduced species. Windmillgrass (Chloris spp.) and Texas wintergrass (Stipa leucotricha) dominated vegetation on native areas. Bristlegrasses (Setaria spp.) and forbs, principally sida (Sida spp.) and western ragweed (Ambrosia psilostachya), dominated vegetation on areas that had been rootplowed twice about 10 years prior to the study. A moderately dense shrub stratum, consisting mainly of huisache (Acacia farnesiana), honey mesquite (Prosopis glandulosa), and granjeno (Celtis pallida), was present on both native and rootplowed areas.

Snap-trap transects were established to index cotton rat density, including 5, 8, and 14 transects on improved, native, and rootplowed areas, respectively. Twenty-two traps, baited with rolled oats, were placed at 5-yard intervals in each 10-yard transect. Traps were operated from 1700 to 2000 hours the first and second days of trapping and from 0700 to 1000 hours the second day. The lines were run at $1-\mathrm{hr}$ intervals during each 3 -hr period. The dependent variable used in subsequent analyses was the total number caught per $9 \mathrm{hr}$. Weather, which influences probability of capturing rodents, was uniform during the study.

Standing crop biomass of vegetation was determined by clipping a $25-\mathrm{ft}^{2}$ plot adjacent to and at the center of the 27 snap-trap transects. The clippings were weighed wet, air-dried, and weighed dry to the nearest ounce. Species composition of vegetation along the transects was estimated visually.

Twenty-two independent variables (Table 1) were examined as habitat features that may have influenced cotton rat density. Besides determining univariate correlations, we used for maximum $R^{2}$ option of the stepwise multiple regression procedure of SAS (Barr et al. 1976) to select the best four-variable model for predicting cotton rat density. We combined the percentage composition of certain plant taxa to create independent variables because their growth forms were similar. Both composition and physiognomy are important features of habitat.

\section{Results and Discussion}

A total of 680 cotton rats was captured on the 27 transects. The mean catches per $9 \mathrm{hr}$ were significantly different $(\mathrm{P}<0.01)$ on native $(6.1 \pm 1.1)$, improved (23.6 \pm 1.4$)$, and rootplowed $(36.6 \pm 4.7)$ areas. The means suggest that cotton rat density was about four times higher on improved areas and about six times higher on rootplowed areas, when compared to native areas. 
Table 1. Independent variables used to develop a model for cotton rat density in Kleberg County, Texas, in August 1976 and simple correlations $(r)$ with the density index.

\begin{tabular}{lc}
\hline \hline Variables & $r$ \\
\hline Standing crop biomass of herbaceous vegetation (wet) & $0.44^{\star}$ \\
Standing crop biomass of herbaceous vegetation (dry) & $0.52^{\star \star}$ \\
Mean height of herbaceous vegetation & 0.07 \\
Number of genera in clippings (diversity) & $0.39^{\star}$ \\
Number of downed logs along transect & 0.31 \\
Percentage composition of standing crop by & \\
all forbs & 0.25 \\
Iva plus Ambrosia & 0.13 \\
forbs less Iva and Ambrosia & -0.20 \\
Iva & 0.27 \\
Ambrosia & -0.02 \\
Sida & $0.76^{\star \star}$ \\
all grasses & -0.26 \\
panicoid grasses & $0.46 \star$ \\
nonpanicoid perennial grasses less Stipa and Chloris & 0.03 \\
Paspalum plus Panicum & 0.27 \\
Chloris plus Stipa & $-0.50^{\star \star}$ \\
annual grasses plus Chloris & -0.29 \\
Setaria & $0.57^{\star \star}$ \\
Stipa & -0.37 \\
Chloris & -0.25 \\
annual grasses plus Chloris and Stipa & -0.38 \\
brush & -0.01 \\
\hline Significa & \\
\hline
\end{tabular}

* Significant at $P<0.01$.

* Significant at $P<0.05$.

Univariate correlations revealed that the percentage composition of sida was the most powerful predictor of cotton rat density (Table 1). Cotton rat density also was correlated positively with percentage composition of the standing crop furnished by bristlegrasses, standing crop biomass of herbaceous vegetation, and number of genera per clipping. Density was negatively correlated with percentage composition of Texas wintergrass plus windmillgrasses.

A four-variable regression model $(P>0.0001)$ accounted for $81.4 \%$ of the variation in the cotton rat density index. The partial regression coefficients indicated that the catch per $9 \mathrm{hr}$ increased by one animal with each increment of (1) $2 \mathrm{oz} / 25 \mathrm{ft}^{2}$ in standing crop biomass (dry) of herbaceous vegetation $(P<0.01),(2) 1.1 \%$ in percentage composition of sida $(P<-$ $0.05)$, (3) $2 \%$ in percentage composition of bristlegrass $(P<0.05)$, and $(4) 4 \%$ in percentage composition of the variable sumpweed (Iva sp.) plus western ragweed $(P<0.05)$. These figures may be valid only within the range of values recorded in this study.

The apparent importance of sida to cotton rat habitat is difficult to explain. Sida apparently provides little cover, but the seeds and herbage may serve as food. However, since correlation does not necessarily indicate a cause-effect relationship, presence of sida may only reflect other habitat parameters that truly influenced cotton rat abundance. For example, percentage composition of the standing crop furnished by sida was correlated with number of species per clipping $(r=0.59$, $P<0.01)$ and with percentage composition of the standing crop furnished by bristlegrasses $(r=0.51, P<0.01)$. The latter two variables, as previously discussed, were positively correlated with cotton rat density. Also, sites with more sida had lower percentages of Texas wintergrass plus windmillgrass ( $r=$ $-0.38, P<0.06$ ), and this variable was negatively correlated with the density index.

The importance of standing crop biomass in determining cotton rat density was expected. These animals attain greater
Table 2. Comparison of cotton rat habitat parameters based on average values by range treatment, Kleberg County, Texas.

\begin{tabular}{lccc}
\hline & \multicolumn{3}{c}{ Range treatment } \\
\cline { 2 - 4 } $\begin{array}{l}\text { Habitat } \\
\text { parameter }\end{array}$ & $\begin{array}{c}\text { Improved } \\
(\mathrm{n}=5)\end{array}$ & $\begin{array}{c}\text { Native } \\
(\mathrm{n}=8)\end{array}$ & $\begin{array}{c}\text { Rootplowed } \\
(\mathrm{n}=14)\end{array}$ \\
$\begin{array}{l}\text { Standing crop biomass } \\
\quad\left(\mathrm{lb} / 25 \mathrm{ft}^{2}, \text { dry) }\right.\end{array}$ & 3.1 & 1.8 & 2.3 \\
$\begin{array}{l}\text { Diversity }(\mathrm{number} \text { of } \\
\left.\text { genera/25 } \mathrm{ft}^{2}\right)\end{array}$ & 4.2 & 6.4 & 8.4 \\
$\begin{array}{l}\text { Percentage composition of } \\
\text { standing crop by }\end{array}$ & & & \\
$\quad \begin{array}{l}\text { bristlegrasses } \\
\text { sida }\end{array}$ & 8.0 & 1.9 & 7.9 \\
$\quad \begin{array}{l}\text { sumpweed } \text { plus ragweed } \\
\text { Texas wintergrass } \text { plus }\end{array}$ & 0.0 & 2.9 & 12.4 \\
$\quad$ windmillgrass & 1.4 & 3.1 & 15.6 \\
\hline
\end{tabular}

abundance at higher successional levels (Phillips 1936), and standing crop biomass increases with succession. Also, standing crop biomass varies directly with structural vegetative cover, which, in our experience, is an indicator of habitat preferred by cotton rats.

Bristlegrasses, sumpweed, and ragweed supply relatively large seeds that are eaten by many species of wildlife (Martin et al. 1951); these foods probably were important to cotton rats. Also, because sumpweed and ragweed are single-stemmed forbs with dense canopy foliage, they provided freedom of movement at ground level with simultaneous concealment from raptors.

Our findings generally agree with those of other studies in south Texas. Powell (1968), working in San Patricio County, found that rodent populations comprised primarily of pygmy mice (Baiomys taylori) had higher densities on rootplowed than on untreated areas. However, scalping with a blade and rootplowing and raking resulted in lower densities than on untreated areas. Powell concluded that the cover provided by downed brush contributed to the attractiveness of rootplowed areas to rodents, which would tend to support our observations.

Guthery $(1977,1978)$ trapped four sites in Zavala County, Texas. His data indicated that during 1975 the site which supported the highest standing crop biomass of herbaceous vegetation and the greatest percentage composition of western ragweed experienced a cotton rat irruption, whereas populations were stable or increased slightly on other sites. The irrupting population crashed, however, in 1976, during a period of low rainfall.

\section{Conclusions}

Range rehabilitation in south Texas provided habitat conditions that were suitable for high cotton rat populations in 196I. The mechanisms involved appeared to be an increase in standing crop biomass of herbaceous vegetation and increases in the percentage composition of standing crop by plant taxa that potentially supply food to cotton rats, namely bristlegrasses, sumpweed, and ragweed (Table 2). Percentage composition of sida, though highly correlated with our density index, likely reflected other habitat features that were truly attractive to cotton rats. Cotton rats achieved the highest densities on rootplowed areas that supported a diverse flora composed principally of lower-successional forbs and grasses.

\section{Literature Cited}

Barr, A.J., J.H. Goodnight, J.P. Sall, and J.T. Helwig. 1976. A user's guide to SAS 76. SAS Institute, Inc., Raleigh, North Carolina. 329 p. 
Batzli, G.O., and F.A. Pitelka. 1970. Influence of meadow mouse populations on California grassland. Ecology 51:1027-1039.

Bond, R.M. 1945. Range rodents and plant succession. Trans. N. Amer. Wildl. Conf. 10:299-233.

Chew, R.M., and A.E. Chew. 1970. Energy relationships of the mammals of a desert shrub (Larrea tridentata) community. Ecol. Monogr. 40:1-21. Davis, W.B. 1974. The mammals of Texas. Texas Parks and Wildl. Dep. Bull 41 (Rev.). 294 p.

Fitch, H.A., and J.R. Bentley. 1949. Use of California annual-plant forage by range rodents. Ecology 30:306-321.

Foster, R.B. 1965. Effect of heavy winter rodent infestation on perennial forage plants. J. Range Manage. 18:286-287.

French, N.W., W.E. Grant, W. Grodzinski, and D.M. Swift. 1976. Small mammal energetics in grassland ecosystems. Ecol. Monogr. 46:201-220.

Gross, J.E. 1969. The role of small herbivorous mammals in the functioning of grassland ecosystem. In: The Grassland Ecosystem, R.L. Dix and D S. Raidlaman (Fde) Ranoe Sci. Den. Sci. Ser. No. 2, Colorado
Guthery, F.S. 1977. Efficacy and ecological effects of predator control in south Texas. PhD Thesis. Texas A\&M Univ. 50 p.

Guthery, F.S. 1978. Rodent movements in south Texas and their relation to density estimates. Proc. Southeastern Assoc. of Fish and Wildl. Agencies. 31: (In press).

Haines, H. 1963. Geographical extent and duration of the cotton rat, Sigmodon hispidus, 1958-1960 fluctuation in Texas. Ecology 44:771-772.

Martin, A.C., H.S. Zim, and A.L. Nelson. 1951. American Wildlife and Plants. Dover Publications, Inc., New York. 500 p.

Norris, J.J. 1950. Effect of rodents, rabbits, and cattle on two vegetation types in semi-desert rangeland. New Mexico Agr. Exp. Sta. Bull. 353. 23 p.

Phillips, P. 1936. The distribution of rodents in overgrazed and normal grasslands of central Oklahoma. Ecology 17:673-679.

Powell, J. 1968. Rodent numbers on different brush control treatments in south Texas. Texas J. Sci. 20:69-76.

Vallentine, J.F. 1971. Range Developments and Improvements. Brigham Young Univ. Press. Provo. 515 p. 